\title{
st|: \\ LABORATORY FOR GEOLOGY AND MINERALOGY AT OXFORD
}

$\mathrm{O}^{\mathrm{N}}$ February 9, 1937, the University of Oxford launched a wopld-wide appeal for money for a number of major pojects, mostly for urgently needed science but ing, and among these was a Department of Geplpgy OThe situation at that time was such that the wate of an article in Oxford ${ }^{1}$, the journal of the Oxford Society suggested that "one cannot in defency as new professor (not yet appointed) to take ore the cramped quarters in the Museum where geology is now housed, however tolerable his predecessor may have found them".

In response to this appeal, the Shell Petroleum Company made the very substantial contribution of $£ 25,000$ towards the cost of a new building, and plans were drawn up for a new department which would replace the Clarendon Laboratory on the north-west flank of the University Museum as soon as Prof. Lindemann (now Lord Cherwell) had transferred his Department of Physies to a new building. This essential move was scarcely completed when war eame, and for the time being all further activity was postponed.

As soon as the War ended, the plans were taken up again; some modifications were necessary when it was decided that the Department of Mineralogy should also be transferred to the new building. It was largely due to the enthusiasm and energy of Prof. J. A. Douglas, head of the Department, that work began so soon after the end of the War, so that the new Department of Geology and Mineralogy is thus the first science building to be completed in Oxford in the post-war period. With the very large increase in the numbers of undergraduates reading geology in the past four years, conditions for teaching in the old laboratory in the Museum became well-nigh intolerable, and there has been a gradual transference to the new building as it became available, beginning with temporary laboratory accommodation in the workshops.

The building was formally opened on July 7 by the Vice-Chancellor of the University, the Very Rev. A. J. Lowe, dean of Christ Church. Besides members of the University, numerous geologists, mineralogists and representatives of the oil-producing companies were present at the ceremony. After speeches by the Vice-Chancellor, by Mr. J. W. Platt, managing director of the Shell Petro. leum Company, and by Prof. Douglas, the company was conducted around an exhibition of oilfield de. velopment which has been arranged within the Department by a committee representing the major producing companies of the British oil industry (see p. 153).

The new Department consists partly of a new building of three stories and partly of a reconstruction of the Clarendon Laboratory. The new section, which is $103 \mathrm{ft}$. in length and $35 \mathrm{ft}$. wide, forms the west side of the Department and faces Keble College. To first-floor level the external walls are faced with tooled ashlar of Clipsham stone from the Inferior Oolite, and above this, punch-faced walling of Bladon stone from Bladon near Woodstock from the Forest Marble formation is used with Clipsham dressings. The floors and flat roof are of reinforced concrete hollow-tile construction, and the floors are covered with Southern Rhodesian teak blocks. The accommodation in this section consists of two large teaching laboratories on ground- and first-floor, a small library in which are displayed manuscripts and original maps of William Smith and other historical material, and also on the first floor the professor's room and private laboratory. The top-floor is given over to the lecturers' private research rooms and to photographic rooms.

The reconstructed portion still retains the central hall and original staircase of the old Clarendon Laboratory. The main entrance has been placed on the south side and the whole of this front refaced with Bladon and Clipsham stone. On the north side of this section of the building are the petrological and chemical laboratories on the ground floor. Above these are the rooms occupied by the reader in mineralogy, Mr. R. C. Spiller. Here, there is a teaching laboratory which can also be used as a lecture room, a physical laboratory, lecturers' rooms and the Herbert Lister Bowman Library containing the valuable library of the late professor of mineralogy, presented to the Department, together with an endowment fund of $£ 1,000$, by his widow.

The large lecture theatre of the Clarendon Laboratory occupying the east side of the block of buildings has been taken over and remains in its original

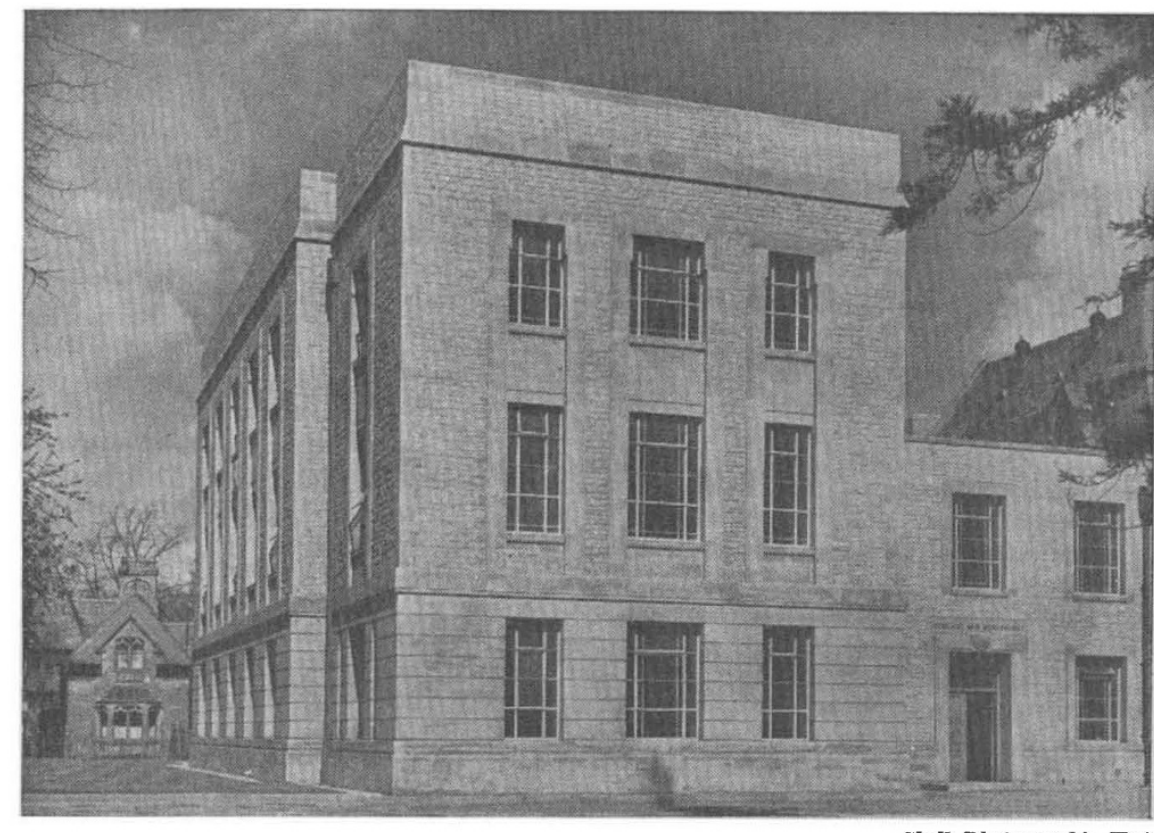

New Geological Laboratory at Oxford 
form externally. Certain modifications have been made internally; but it is expected that eventually a properly equipped lecture theatre of modern design will be built on this site.

The workshops are single-story rooms adjacent to the main structure and are equipped for rock and mineral sectioning and polishing. There are extensive cellars below the reconstructed building and they are being used for storage. In them was done perhaps the best-known research work in the old Clarendon, namely, Vernon Boys's classic determination of the gravitation constant.

It will be a source of great satisfaction to Prof. Douglas that the transfer of the Department has been carried through during his tenure of the chair in spite of the interruption of the War and the great pressure on building since then. Not only will he eventually leave his successor a spacious teaching department, but also he is now able to accommodate the present greatly increased numbers of undergraduates reading for Moderations and Finals. His staff also will be grateful for the excellent rooms which they now have.

It could only be expected in such times as follow wars that there has had to be a certain amount of improvisation in some directions, and certain desirable items of equipment are still awaited. It must be added, too, that the lecture room will one day have to be entirely reconstructed, and there is a real and urgent need for the proper housing of the research and reference collections, and of a set of rooms for postgraduate and visiting research workers.

J. M. EDMONDS

${ }^{1}$ Russell, A. S., "Oxford and some Needs in Science", Oxford, 3, 39 (1937).

\section{$18 \%$}

\section{AN EXHIBITION OF OILFIELD DEVELOPMENT AT OXFORD}

$T$ HE exhibition of 9 field development which was open to the pulfe during July 8-20 in the new building of the partment of Geology and Mineralogy at Ofor Mras arranged by a committee of the British petro sum industry connexion with the meeting in Oxford of the H@rth Empire Mining and Metallurgical Congress and in order to commemorate the opening of the new building. It is also particularly appropriate that it should have been during "Colonial Month" that the exhibition presented the search for oil and the devel pment of oilfields in countries where British and Commonwealth enterprise has taken the lead.

Since the exploration for and development of oilfields is the foundation of the whole petroleum industry, emphasis in the exhibition was laid chiefly upon the geological and related sciences upon which oil exploration and extraction methods are based, though there were displays showing the wide, and to the outsider, the surprising, range of petroleum products; while the film programmes, shown several times daily throughout the exhibition, dealt with all aspects of oil finding, extraction, transport, refining, and fundamental research into problems such as atomization and microscopy.

The focus of the exhibition was the world map showing the distribution of the oil- and gas-fields of the world and the sedimentary or 'oil' basins spread across the continents, and similar distinctive maps on a larger scale introduced the panels devoted to each country or area separately. One large exhibition room was devoted to countries within the Commonwealth, and by means of topographical and geological maps, sections and photographs of general and specialized nature, the exhibitors were able to hold the interest of visitors of widely varying technical knowledge; further, by series of beautiful photographs, they held the interest of visitors without technical knowledge. It is worthy of remark that here some were first introduced to the fact that there is a producing field at Eakring in Nottinghamshire. The gallery surrounding the central well of the building was given over to displays from the Middle East and Burma, where British enterprise has long taken the lead.

Within the Technical Room (or upper students' laboratory) the applications of the sciences, harnessed to the service of the oil industry, were explained in as 'popular' a manner as possible. Palæontology and the diagnostic value of the micro-fossil content of the rocks had their place, and the visitor was led on to examine the intricacies of geophysical exploration. Specially notable exhibits were the gravity and magnetic maps of southern England not shown in public previously. There was also included the geotectonic map of north-west Germany made by the German Geological Survey (British Zone) under Military Government in the two years after the War (London: H.M. Stationery Office. Scale $1: 100,000$. 25 sheets, $£ 10$ ).

Of the several working models, the outstanding one was of the Schoonebeek oilfield lying across the DutchGerman frontier. This oilfield is now one of the largest in Europe, and it is only because the Dutch successfully deferred its development for four years that the Germans were unable to make use of it to any great extent during the War.

There were displays of drilling and production equipment by several firms, including a modern counterbalanced gear-driven pumping unit which was in action throughout the period of the exhibition. Apart from an impressive display on the second floor of the building by the British Instrument Manufacturers' Association, there were smaller displays of instruments used in surveying and in the exploration for oil.

The British petroleum industry is to be congratulated on the success of this major venture into the educational field, and on the enterprise shown in bringing before the general public this demonstration of the harnessing of pure and of applied science to the needs of one of the most important industries of our day.

\section{SOME ANISOTROPIC PROPERTIES OF GALLIUM}

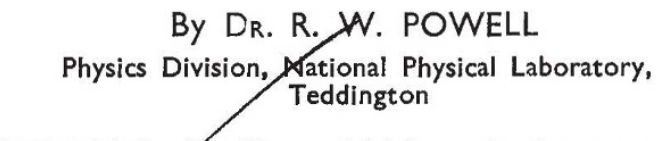

CAMPLES of gallium of high purity have recently $\checkmark$ become/available for experimental purposes through the work of the Chemical Research Laboratory on the extraction of this metal from flue deposits ${ }^{1}$. Early this year, a few rods of the metal were supplied to the Physics Division of the National Physical Laboratory for the purpose of investigating some of the thermal and electrical properties of the solid and liquid phases (the melting point is just 